University of Nebraska - Lincoln

DigitalCommons@University of Nebraska - Lincoln

Faculty Publications from the Harold W. Manter Laboratory of Parasitology

4-1976

Immunoglobulins Attached to and in the Integument of Adult Schistosoma mansoni Sambon 1907, from First Infection of $\mathrm{CF}_{1}$ Mice

Franklin Sogandares-Bernal

Southern Methodist University, fsogandares@wildblue.net

Follow this and additional works at: https://digitalcommons.unl.edu/parasitologyfacpubs

Part of the Parasitology Commons

Sogandares-Bernal, Franklin, "Immunoglobulins Attached to and in the Integument of Adult Schistosoma mansoni Sambon 1907, from First Infection of $C_{1}$ Mice" (1976). Faculty Publications from the Harold W. Manter Laboratory of Parasitology. 479.

https://digitalcommons.unl.edu/parasitologyfacpubs/479

This Article is brought to you for free and open access by the Parasitology, Harold W. Manter Laboratory of at DigitalCommons@University of Nebraska - Lincoln. It has been accepted for inclusion in Faculty Publications from the Harold W. Manter Laboratory of Parasitology by an authorized administrator of DigitalCommons@University of Nebraska - Lincoln. 


\title{
IMMUNOGLOBULINS ATTACHED TO AND IN THE INTEGUMENT OF ADULT SCHISTOSOMA MANSONI SAMBON 1907, FROM FIRST INFECTION OF CF $_{1}$ MICE
}

\author{
F. Sogandares-Bernal \\ Department of Biology, Southern Methodist University, Dallas, Texas 75275, and \\ Department of Pathology, Baylor Medical Center, Dallas, Texas 75246
}

ABSTRACT: $7 \mathrm{~S}_{\gamma 2 \mathrm{~b}}$ antibody was found attached to and in the integument of adult Schistosoma mansoni removed from $\mathrm{CF}_{1}$ white mice. With the techniques used, $\mathrm{I}_{\mathrm{g}} \mathrm{A}, \mathrm{I}_{\mathrm{g}} \mathrm{M}, 7 \mathrm{~S}_{\gamma 1}, 7 \mathrm{~S}_{\gamma 2 \mathrm{a}}, 7 \mathrm{~S}_{\gamma 3}$, and $\mathrm{C} 3 \mathrm{com}$ plement were not found to be attached to the integumental surfaces. $7 \mathrm{~S}_{\gamma 2 \mathrm{~b}}$ does not seem to fix $\mathrm{C} 3$, and it is suggested this antibody may be acting in enhancing and blocking roles which protect the worms from the host.

The reason for survival of adult $S$. mansoni in their normal habitus has never been adequately explained. Damian (1964) postulated the phenomenon of "molecular mimicry" to explain why the host does not recognize the worms as foreign. Clegg (1974) has reviewed, in some detail, the evidence for the presence of hostlike antigenic determinants on the surface membranes of adult schistosomes.

Apparently the survival of the adult schistosomes in the blood vessels of their host has never been examined from the viewpoint of possible blocking action by certain antibody types. This is surprising in view of the rapidly expanding literature in this area of cancer research. Cohen and Milstein (1962) and Speigelberg (1974) have already indicated that immunoglobulin types differ in their biological activities. Winn (1960) and Moller and Moller (1962) have shown that the ability to bind complement will determine if a specific immunoglobulin will be cytolytic, or if it may act as a blocking agent (Hellström et al., 1969). Coe and Takemoto (1972) have shown how Syrian hamster $7 \mathrm{~s}_{\gamma 1}$ may coat SV40-induced tumors and because this antibody type precedes $7 \mathrm{~S}_{\gamma_{2}}$ and usually does not fix complement via the classical pathway, it may act as a blocking antibody-enhancing tumor growth.

In view of the above cited evidence, it was decided to examine the antibody types attached to the integument of adult S. mansoni from first infection of the laboratory white mouse. It was hypothesized that an antibody type might be attached to the integument of the

Received for publication 5 September 1975. worms which would preclude complement fixation and hence prevent damage to the cell surfaces of the parasite. The experiments described below show the results of my investigations.

\section{MATERIALS AND METHODS}

Female Carworth $\mathrm{CF}_{1}$ mice, each exposed to about 200 cercariae ip, were obtained through the courtesy of the U. S.-Japan Cooperative Medical Science Program, National Institute of Allergy and Infectious Diseases, U. S. Public Health Service, in cooperation with the University of Michigan. Infections used were of 8 to 10 weeks duration.

The infected mice were killed by cervical dislocation and the worms were removed by forceps from the mesenteric blood vessels. The worms were then washed clean in phosphate-buffered saline (PBS) at pH 7.2 with the aid of a dissecting microscope, collected in small clusters, frozen in liquid nitrogen or in a cryostat $(-25 \mathrm{C})$ on a microtome chuck containing a drop of Cryoform ${ }^{\circledR}$ (Damon/IEC Division). Sections were cut at 10 $\mu \mathrm{m}$ in an American Optical (Buffalo, N. Y.) "Cryo-Cut" rotary freezing microtome. The sections were then attached to prechilled ( $-25 \mathrm{C}$ ) slides, precoated with $0.75 \%$ gelatin, by bringing them to body temperature.

Sections of the worms were treated with antimouse antibodies, both fluorescein-conjugated and unlabeled, of different classes and subclasses (see Table I and this section for details of antibody type, sources, and lot numbers), and examined with the aid of an American Optical (Buffalo, N. Y.) reflected fluorescence microscope equipped with an HBO $50 \mathrm{~W}$ burner, BG12+KV418 exciters and OG515 barrier filters, and a $500-\mathrm{nm}$ dichroic beamsplitter. Corresponding controls for each class or subclass of antimouse fluoresceinconjugated immunoglobulins were performed by pretreatment with the appropriate nonlabeled immunoglobulin for $30 \mathrm{~min}$ followed by a $30-\mathrm{min}$ wash in PBS before treatment with the conjugated goat or rabbit antimouse immunoglobulin. After treatment with the labeled immunoglobulin the 
slides were again washed in PBS for $30 \mathrm{~min}$ before mounting in Coon's buffered glycerin at $\mathrm{pH}$ 7.31 .

All antiserums were tested for purity by reacting them against the appropriate antigens by the Ouchterlony technique. The antiserums were also tested by immunoelectrophoresis. In both cases single precipitin bands were observed when reacted against either the specific antigen or serum taken from mice infected with $S$. mansoni.

Fluorescein-conjugated $\mathrm{I}_{\mathrm{g}} \mathrm{G}$ fraction of rabbit antimouse $7 \mathrm{~S}_{\gamma^{2 b}}$ was produced as follows: $\mathrm{CDF}_{1}$ mouse (MOPC 195) $7 \mathrm{~S}_{\gamma 2 \mathbf{b}}$ was obtained from Litton Bionetics Laboratories, Kensington, Md. This myeloma antibody was first reacted in Ouchterlony plates against antimouse $I_{g} A, I_{g} G$, $7 \mathrm{~S}_{\gamma 2 \mathrm{a}}, 7 \mathrm{~S}_{\gamma \mathrm{2b}}, 7 \mathrm{~S}_{\gamma 3}$, and $\mathrm{I}_{\mathrm{g}} \mathrm{M}$ and was observed to produce a single line only when reacted against rabbit antimouse $7 S_{\gamma_{2 b}}$ antibody and $I_{g} G$. This protein was then mixed in Freund complete adjuvant and injected (30 $\mu \mathrm{g}$ protein/animal) equally between the hindfoot-pads of two male New Zealand white rabbits weighing approximately $3 \mathrm{~kg}$. The animals were boosted with the antigen $(30 \mu \mathrm{g} /$ animal $)$ via the ear vein on day 11 , and again on day 22 via the same route. Precipitating titers from serums collected from the ear and reacted against the antigen were observed to be $1: 8$ and $1: 2$ on day 15 , and $1: 16$ and $1: 2$ on day 22 when the animals were killed, bled out, and their serums collected. Approximately 7 $\mathrm{ml}$ of serum collected on day 15 from the ear of the rabbit with the 1:8 precipitating titer was batch processed in medium mesh Diethylaminoethyl Cellulose (DEAE-Cellulose) (Lot No. 25C0173, Sigma Chemical Co., St. Louis, Mo.) after the manner of Peterson and Sober (1956) as modified by Stanworth (1960). The volume was reduced in Carbowax M20 (Union Carbide Co., Chicago, Ill.) following the method of Kohn (1959) to $5 \mathrm{ml}$. This fraction, after overnight dialysis against PBS, pH 7.3, had by my methods a precipitating titer of $1: 2$ and a protein content of $7.3 \mu \mathrm{g} / \mathrm{ml}$ as determined by a Biuret micromethod (kindly determined by Dr. J. L. McCarthy of this department). The antibody resulting from the above method was then labeled with fluorescein isothiocyanate isomer 1 (Lot No. 104C5026, Sigma Chemical Co., St. Louis, Mo. ) following the method of Clark and Shepard (1963) by dialysis. The conjugate was then dialyzed in repeated changes of $\mathrm{PBS}, \mathrm{pH} 7.3$ at $4 \mathrm{C}$, until the dialysate no longer showed fluorescence when exposed to long-wave UV in the dark. The labeled antibody was then removed from the dialysis tubing and frozen until ready for use. $\mathrm{F} / \mathrm{P}$ ratios were not conducted since the sample was too small, but the labeled antiserum was used undiluted.

The experiments were repeated 3 times using worms from different mice. The single exception was antimouse $I_{g A}$ which was tested on worms from a single mouse. Antibody reactions were performed in duplicate.

\section{RESULTS}

Identical responses were obtained in each replicate of the three trials. Table II shows the results obtained. No $\mathrm{I}_{\mathrm{g}} \mathrm{A}, \mathrm{I}_{\mathrm{g}} \mathrm{M}$, or $\mathrm{C} 3$ activity was detected on the surface of the schistosomes. $\mathrm{I}_{\mathrm{g}} \mathrm{G}$ was present and the fluorescence could only be blocked with $7 \mathrm{~S}_{\gamma 2 \mathrm{~b}}$ antibody and the corresponding unlabeled $\mathrm{I}_{\mathrm{g}} \mathrm{G}$, H\&L-chain. The surfaces and integument of the worm stained apple green with labeled antimouse $7 \mathrm{~S}_{\gamma 2 \mathrm{~b}}$ and the reaction could be blocked with pretreatment with unlabeled antimouse $7 \mathrm{~S}_{\gamma 2 \mathrm{~b}}$. Under very high power the staining seemed to extend to the perikarya. It is therefore presumed that the antibody subclass attached to the surfaces of the adult schistosomes and present in their integument in infection of the laboratory mouse is $7 \mathrm{~S}_{\gamma 2 \mathrm{~b}}$ and that no $\mathrm{C} 3$ complement fixations occur with this antibody.

\section{DISCUSSION}

The results reported above should be observed with some caution. In spite of the fact that the mouse H-chain subclasses of $I_{g} G$ used to produce the antimouse immunoglobulins used in this study were as "clean" as could be obtained, the results reported herein must be subject to the following considerations. Munoz (1971) has already indicated that various workers erroneously assume purity when a single precipitin band is obtained in gel diffusion techniques, when in fact a single band does not always indicate chemical or immunological purity. Melcher et al. (1974) have indicated that reactivity may occur between purified portions of mouse $\gamma, \delta$, and $\mu$ chains after extensive absorption with L-chains. Such crossreactivity has been suggested by Kunkel (in Vitetta and Uhr, 1975) to be due to the polypeptide portion of the $\mathrm{H}$-chains and to the differing carbohydrate contents of the chains by Melcher et al. (1974) and Merler et al. (1974). The fact that consistent results using worms from different mice were observed in this study suggests that the sensitivity of the tests used in this study were not within the range at which such cross-reactivity interfered or could be detected.

While more or less a problem of semantics, the classification of Fahey et al. (1964a, b) has been used in this study for mouse $\mathrm{I}_{\mathrm{g}} \mathrm{G}$ 
TABLE I. Immunoglobulins used, their sources, and lot numbers.

\begin{tabular}{|c|c|c|}
\hline Immunoglobulin type & Source & Lot No. \\
\hline$I_{g} G$ fraction rabbit antimouse $I_{g} G$, H\&L-chain & $\begin{array}{l}\text { Cappel Laboratories, } \\
\text { Downingtown, Pa. }\end{array}$ & 7678 \\
\hline $\begin{array}{l}\text { Fluorescein-conjugated } I_{g} G \text { fraction } \\
\text { rabbit antimouse } I_{g} G, H \& L \text {-chain }\end{array}$ & Cappel Laboratories & 7801 \\
\hline Rabbit antimouse $\gamma \mathrm{Gl}$ & $\begin{array}{l}\text { Litton-Bionetics Laboratories } \\
\text { Kensington, Md. }\end{array}$ & $231-57-2$ \\
\hline Rabbit antimouse $\gamma$ G2a & Litton-Bionetics Laboratories & $231-57-4$ \\
\hline Rabbit antimouse $\gamma$ G2b & Litton-Bionetics Laboratories & $231-57-5$ \\
\hline $\mathrm{CDF}_{1}$ Mouse (MOPC 195) $\gamma \mathrm{G} 2 \mathrm{~b}$ & Litton-Bionetics Laboratories & $231-5-2$ \\
\hline $\begin{array}{l}\text { Fluorescein-conjugated } I_{g} G \text { fraction } \\
\text { rabbit antimouse } \gamma \mathrm{G} 2 \mathrm{~b}\end{array}$ & $\begin{array}{l}\text { Produced in this laboratory } \\
\text { (see Materials and Methods) }\end{array}$ & - \\
\hline Rabbit antimouse $\gamma \mathrm{G} 3$ & Litton-Bionetics Laboratories & $231-57-6$ \\
\hline $\mathrm{I}_{\mathrm{g}} \mathrm{G}$ fraction goat antimouse $\mathrm{I}_{\mathrm{g}} \mathrm{M}, \mu$-chain & Cappel Laboratories & 6993 \\
\hline $\begin{array}{l}\text { Fluorescein-conjugated } I_{g} G \text { fraction goat } \\
\text { antimouse } I_{g} M, \mu \text {-chain }\end{array}$ & Cappel Laboratories & 6994 \\
\hline $\begin{array}{l}I_{g} G \text { fraction rabbit antimouse complement } \\
\text { C } 3\left(B_{1} C / B_{1} A\right)\end{array}$ & Cappel Laboratories & 6553 \\
\hline $\begin{array}{l}\text { Fluorescein-conjugated } \mathrm{I}_{\mathrm{g}} \mathrm{G} \text { fraction rabbit } \\
\text { antimouse complement } \mathrm{C} 3\left(\mathrm{~B}_{1} \mathrm{C} / \mathrm{B}_{1} \mathrm{~A}\right)\end{array}$ & Cappel Laboratories & 7114 \\
\hline Rabbit antimouse $\mathrm{I}_{\mathrm{g}} \mathrm{A}$ & Litton-Bionetics Laboratories & $231-57-1$ \\
\hline Fluorescein-conjugated goat antimouse $I_{g} A$ & $\begin{array}{l}\text { Meloy Laboratories, } \\
\text { Springfield, Va. }\end{array}$ & 52285 \\
\hline
\end{tabular}

subclasses since it denotes the physical properties more closely than the other classifications such as those of Potter and Lieberman (1967a, b). The results obtained in the mouse should not be construed as necessarily applicable to other animals, and most especially the human. Grey et al. (1971) have already warned that since there is growing evidence that the various $\mathrm{I}_{\mathrm{g}} \mathrm{G}$ subclasses may have evolved after the major mammalian groups diverged, there is no compelling reason for the subclasses of one mammalian species to be functionally or structurally very closely related to those of other species. They further indicated, with reference to subclasses of $\mathrm{I}_{\mathrm{g}} \mathrm{G}$, “. . . that mouse subclasses diverged from one another earlier than human subclasses and are thereby structurally less similar to one another than the human subclasses."

My findings of $7 \mathrm{~S}_{\gamma 2 \mathrm{~b}}$ on the surfaces and in the integument of the worms is consistent with the results of Damian et al. (1973) who reported mouse $\gamma \mathrm{G}_{2}$ in $\mathrm{S}$. mansoni through the use of different techniques. They immunized rabbits with homogenates of worms from mice and detected activity against mouse $7 \mathrm{~S}_{\gamma 2}$ in the serum from the immunized rabbits.

Capron et al. (1974) have shown that $\mathrm{I}_{\mathrm{g}} \mathrm{G}$ fractions of rabbits hyperimmunized with soluble extracts of S. mansoni are cytotoxic to the adults of the same species grown in vitro, but not to similarly treated worms exposed to serum from natural infections. They further showed that the cytotoxicity was dependent upon thermolabile factors in fresh serum, and that the lesions produced did not kill the worms. It should be noted that the Capron et al. (1974) system was run in the absence of activated macrophages. Dean et al. (1974) have recently demonstrated the lethality of $\mathrm{I}_{\mathrm{g}} \mathrm{G}$ in combination with thermolabile serum factors and neutrophiles on schistosomulae in vitro. More recently Capron et al. (1975) have demonstrated the presence of specific $\mathrm{I}_{\mathrm{g}} \mathrm{E}$ acting in its cytophilic mode, attached to peritoneal macrophages of rats. These authors noted significant binding of reaginic antibodycoated macrophages to schistosomulae. No such activity is detected on the surfaces of the adult worms since these are coated with an antibody, $7 \mathrm{~S}_{\gamma 2 \mathrm{~b}}$, which does not seem to fix complement at least in the classical pathway and may serve as both an enhancing and blocking antibody by covering most surface antigenic sites so these are not available for induction of antibody production of other types. Speigelberg (1974) reports that it is not known if mouse $7 \mathrm{~S}_{\gamma 2 \mathrm{~b}}$ fixes complement via 
TABLE II. Antibody types and complement (C3) attached to the integument of S. mansoni from $C F_{1}$ mice.

\begin{tabular}{|c|c|c|c|c|c|}
\hline \multirow[b]{2}{*}{$\begin{array}{l}\text { Antibody block } \\
\text { (nonlabeled) }\end{array}$} & \multicolumn{5}{|c|}{$\begin{array}{l}\text { Fluorescein-conjugated antimouse } \\
\text { complement and } I_{g} \text { types }\end{array}$} \\
\hline & $\begin{array}{c}\mathrm{I}_{\mathrm{g}} \mathrm{G} \\
(\mathrm{H} \& \mathrm{~L}-\mathrm{chain})\end{array}$ & $7 S_{\gamma 2 b}$ & $\begin{array}{c}\mathrm{I}_{\mathbf{g}^{\mathrm{A}}} \\
(a-\text { chain })\end{array}$ & $\begin{array}{c}\mathbf{I}_{\mathbf{g}} \mathbf{M} \\
(\mu \text {-chain })\end{array}$ & C3 $(\mathrm{B}, \mathrm{C} / \mathrm{B}, \mathrm{A})$ \\
\hline Antimouse $I_{g} G, H \& L-c h a i n$ & - & & & & \\
\hline Antimouse $\gamma \mathrm{G} 1$ & + & & & & \\
\hline Antimouse $\gamma$ G2a & + & & & & \\
\hline Antimouse $\gamma \mathrm{G} 2 \mathrm{~b}$ & - & - & & & \\
\hline Antimouse $\gamma \mathrm{G} 3$ & + & & & & \\
\hline Antimouse $\mathrm{I}_{\mathbf{g}} \mathrm{A} \quad(a)$ & + & & - & & \\
\hline Antimouse $\mathbf{I}_{\mathbf{g}}^{\mathbf{6}} \mathbf{M}(\mu)$ & & & & - & \\
\hline Antimouse $\mathrm{C}^{6} 3\left(\mathrm{~B}_{1} \mathrm{C} / \mathrm{B}_{1} \mathrm{~A}\right)$ & & & & & - \\
\hline No block & + & + & - & - & - \\
\hline
\end{tabular}

$(+)$ indicates fluorescence found, $(-)$ tested but fluorescence not found, (blank) not tested.

the classical pathway. As indicated below, the labeled anti-C3 used in these experiments was active since its activity could be detected in egg-induced granulomata. Phillips et al. (1975) have already made suggestions as to the role of antibodies in enhancement in schistosomiasis. Whatever small amounts of surface antigens available on the surface of the antibody-coated worm as might trigger alternate antibody production may instead function to induce tolerogenesis in lymphocytes, perhaps as proposed by Katz (1973).

The chronology of appearance of different antibody types in schistosomiasis has been only lightly studied (Deelder, 1973; El-Hawary et al., 1974). The different antibody types found $\left(\mathrm{I}_{\mathrm{g}} \mathrm{G}\right.$ and $\left.\mathrm{I}_{\mathrm{g}} \mathrm{M}\right)$ in above normal amounts are probably directed towards antigens released by the adult worms, eggs, or other stages in the life cycle. In fact, using the same reagents as for the experiments reported herein, $I_{g} M, 7 S_{\gamma_{1}}$, and complement (C3) activity, has been found to be sequestered in the egg-induced granulomata of the liver in schistosomiasis of mice in this laboratory. These facts suggest that the different types of antibodies produced in schistosomiasis are directed towards different antigens produced by different organs and stages in the life cycle of the parasite. There is little doubt that, as indicated by Clegg (1974), there are hostlike antigens produced by the adult worms. The hypothesis of molecular mimicry postulated by Damian in 1964 might be expected as an evolutionary sequence leading to host-parasite adjustment, but it cannot now be held as the only reason for survival of the adult schistosomes from first infection in the vertebrate host.

Further studies on this topic and upon sequestration of antibody types by egg-induced granulomata are being continued in this laboratory.

\section{ACKNOWLEDGMENTS}

This is to gratefully acknowledge the assistance of Dr. Kenneth O. Phifer, National Institute of Allergy and Infectious Diseases, The National Institutes of Health, and Dr. Harvey D. Blankespoor and Mrs. Henry van der Schalie, The University of Michigan, for providing mice infected with $S$. mansoni under auspices of the U. S.-Japan Cooperative Medical Science Program-NIAID. Dr. John L. McCarthy, Department of Biology, Southern Methodist University, kindly helped by estimating protein content of certain serums by a modified microbiuret technique. Dr. John E. Ubelaker also helped in the laboratory work preparing the labeled anti- $7 \mathrm{~S}_{\gamma 2 \mathrm{~b}}$ fractions.

Grateful acknowledgments are also extended to Dr. George J. Race, Department of Pathology, Baylor Medical Center-Dallas, and to Drs. J. R. Seed and W. M. Kemp, Texas A \& M University, for their presubmission critique of the manuscript.

\section{LITERATURE CITED}

Capron, A., M. Capron, H. Dupas, D. Bout, And A. Petiprez. 1974. Etude in vitro des phenomenes immunologiques dans la schistosomiase humaine et experimentale. 1. Etude comparative in vitro de l'activite lethale 
d'immunserums sur les formes immatures et sur les adultes de Schistosoma mansoni. Int J Parasitol 4: 613-623.

- J.-P. Dessaint, M. Capron, AND $\mathrm{H}$. BAzIN. 1975. Specific $\mathrm{I}_{\mathrm{g}} \mathrm{E}$ antibodies in immune adherence of normal macrophages to Schistosoma mansoni schistosomules. Nature 253 : $474-475$.

Clark, H. E., And C. C. Shepard. 1963. A dialysis technique for preparing fluorescent antibody. Virology 20: 642-644.

Clegg, J. A. 1974. Host antigens and the immune response in schistosomiasis. In Parasites in the Immunized Host. Ciba Foundation Symposium 25 (New Series). Associated Scientific Publishers, New York, p. 161-176.

Coe, J., AND K. K. Takemoto. 1972. Immune response in the hamster. VI. Antibody response in polyoma oncogenesis. J Natl Cancer Inst 49: 39-44.

Cohen, S., AND C. Milstein. 1962. Structure and biological properties of immunoglobulins. Adv Immunol 7: 1-89.

Damian, R. T. 1964. Molecular mimicry: Antigen sharing by parasite and host and its consequences. Am Nat 98: 129-149.

- N. D. Greene, and W. J. Hubbard. 1973. Occurrence of mouse $\alpha_{2}$ macroglobulin antigenic determinants on Schistosoma mansoni adults with evidence of their nature. J Parasitol 59: 64-73.

Dean, D. A., R. Wistar, and K. D. Murrell. 1974. Combined in vitro effects of rat antibody and neutrophilic leukocytes on schistosomula of Schistosoma mansoni. Am J Trop Med Hyg 23 : 420-428.

DeElder, A. M. 1973. Immunology of experimental infections with Schistosoma mansoni in the Swiss white mouse and Fasciola hepatica in the rabbit. Acta Leidensia 39, $107 \mathrm{p}$.

El-Hawary, M. F. S., S. Shoeb, K. Basmy, and A. MAsood. 1974. Immunity against schistosomiasis following antigenization with whole somatic or metabolic worm, cercariae or ova antigens. Proc 3rd Int Congr Parasitol 3: 1248-1249.

Fahey, J. L., J. Wunderlich, and R. Mishell. 1964a. The immunoglobulins of mice. I. Four major classes of immunoglobulins: $7 \mathrm{~S}_{\gamma_{2}-}$, $7 \mathrm{~S}_{1-\gamma 1 \mathrm{~A}}(\beta 2 \mathrm{~A})-$, and $18 \mathrm{~S}_{\gamma 1 \mathrm{M}-}$ globulins. J Exp Med 120: 223-242.

, AND 1964b. The immunoglobulins of mice. II. Two subclasses of mouse $7 \mathrm{~S}_{\gamma^{2}-}$ globulins: $\gamma_{2 \mathrm{a}-}$ and $\gamma_{2 \mathrm{~b}-}$ globulins. J Exp Med 20: 243-251.

Grey, H. M., J. W. Hirst, and M. Cohn. 1971. A new mouse immunoglobulin: $\mathrm{I}_{\mathrm{g}} \mathrm{G} 3$. J Exp Med 133: 289-304.

Hellström, I., K. E. Hellström, and C. A. Evans. 1969. Serum-mediated protection of neoplastic cells from inhibition by lymphocytes immune to their tumor specific antigens. Proc Natl Acad Sci U S A 62: 362368.

KATZ, D. H. 1973. The allogeneic effect on the immune system and its potential application to tumor immunity. In Immunopotentiation. Ciba Foundation Symposium 18 (new series), Elsevier, Holland, p. 141-167.

KoHN, J. 1959. A simple method for the concentration of fluids containing protein. Nature 183: 1055.

Melcher, U., E. S. Vitetta, M. McWilliams, J. Phillips-Quagliata, M. E. Lamm, and J. W. UHR. 1974. Cell surface immunoglobulins. X. Identification of $\mathrm{I}_{\mathrm{g}} \mathrm{D}$-like molecules on the surface of murine splenocytes. J Exp Med 140 : 1427-1431.

Merler, E., J. Gatien, and G. DeWilde. 1974. Significance of immunofluorescence staining of lymphocytes with antisera to $\mathrm{I}_{\mathrm{g}} \mathrm{M}$ immunoglobulins. Nature 251 : 652-654.

Moller, E., AND G. Moller. 1962. Quantitative studies of the sensitivity of normal and neoplastic mouse cells to the cytotoxic action of isoantibodies. J Exp Med 115: 527-533.

Munoz, J. 1971. Double diffusion in plates. In C. A. Williams and M. W. Chase (eds.), Methods in Immunology and Immunochemistry. Academic Press, New York, p. 146-160.

Peterson, E. A., AND H. A. Sober. 1956. Chromatography of proteins. I. Cellulose ion exchange absorbents. J Am Chem Soc 718: 751-755.

Phillips, S. M., W. A. Rem, J. I. Bruce, K. Hedlund, R. C. Colvin, R. Campbell, C. L. Diggs, ANd E. H. SADUN. 1975. The cellular and humoral immune response to Schistosoma mansoni infections in inbred rats. 1 . Mechanisms during initial exposure. Cell Immunol 19: 99-116.

Potter, M., AND R. Lieberman. 1967a. Genetic studies of immunoglobulins in mice. Cold Spring Harbor Symp Quant Biol 32: 187202.

$\longrightarrow$, AND 1967b. Genetics of immunoglobulins in the mouse. Adv Immunol 7: $91-145$.

Speigelberg, H. L. 1974. Biological activities of immunoglobulins of different classes and subclasses. Adv Immunol 19: 259-294.

STANworTH, D. R. 1960. A rapid method of preparing pure serum gamma-globulin. Nature 188: $156-157$.

ViteTtA, E. S., AND J. W. UHR. 1975. Immunoglobulin-receptors revisited. Science 189: 964-969.

WINN, H. J. 1960. Immune mechanisms in homotransplantation. I. The role of serum antibody and complement in the neutralization of lymphoma cells. J Immunol 84: 530-538. 